\title{
Test Excavations at Prehistoric Site 41SM203, Smith County, Texas
}

Glenn T. Goode

Follow this and additional works at: https://scholarworks.sfasu.edu/ita

Part of the American Material Culture Commons, Archaeological Anthropology Commons, Environmental Studies Commons, Other American Studies Commons, Other Arts and Humanities Commons, Other History of Art, Architecture, and Archaeology Commons, and the United States History Commons

Tell us how this article helped you.

This Article is brought to you for free and open access by the Center for Regional Heritage Research at SFA ScholarWorks. It has been accepted for inclusion in Index of Texas Archaeology: Open Access Gray Literature from the Lone Star State by an authorized editor of SFA ScholarWorks. For more information, please contact cdsscholarworks@sfasu.edu. 


\section{Test Excavations at Prehistoric Site 41SM203, Smith County, Texas}

\section{Licensing Statement}

This is a work produced for the Texas Department of Transportation (TxDOT) by the report producer. TxDOT and the report producer jointly own all rights, title, and interest in and to all intellectual property developed under TXDOT's contract with the report producer. The report may be cited and brief passages from this publication may be reproduced without permission provided that credit is given to both TxDOT and the report producer. Permission to reprint an entire chapter, section, figures or tables must be obtained in advance from either the Supervisor of the Archeological Studies Branch, Environmental Affairs Division, Texas Department of Transportation, 125 East 11th Street, Austin, Texas, 78701 or from the report producer. 


\section{Test Excavations at Prehistoric Site 41SM203, Smith County, Texas}

BY

Glenn T. Goode

December 1997

\section{Archeology Studies Program Cultural Resource Management Section Environmental Affairs Division Texas Department of Transportation}




\section{TABle of Contents}

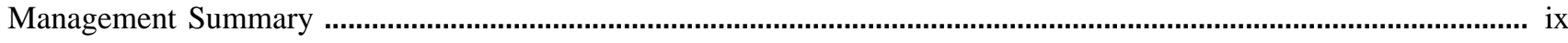

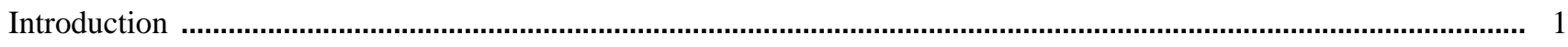

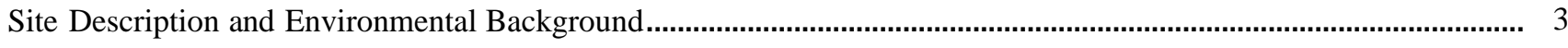

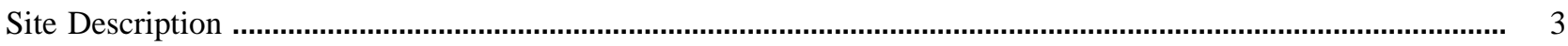

Physiography and Geology ................................................................................................................. 3

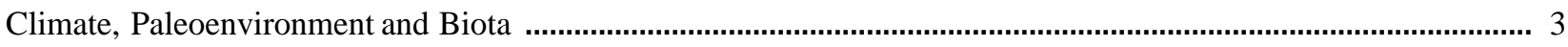

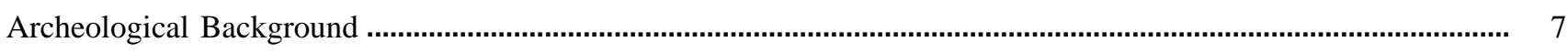

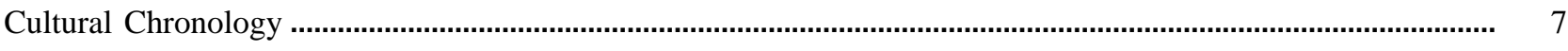

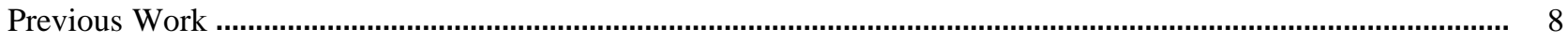

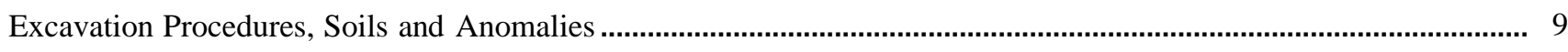

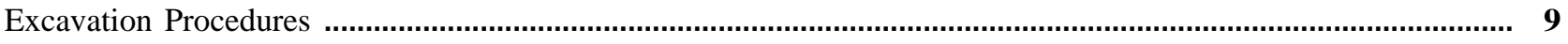

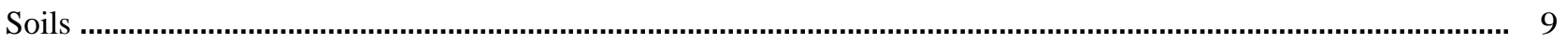

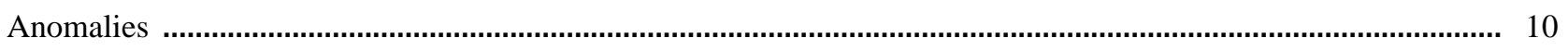

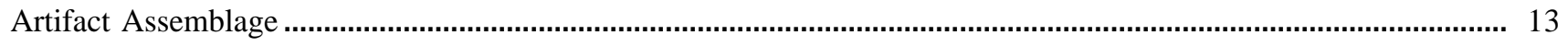

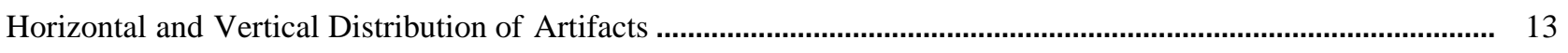

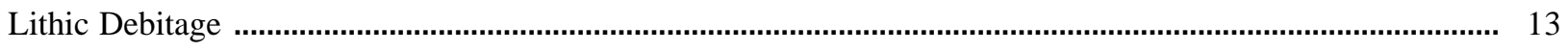

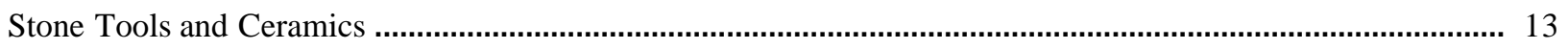

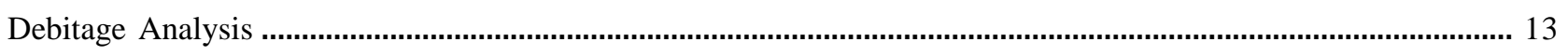

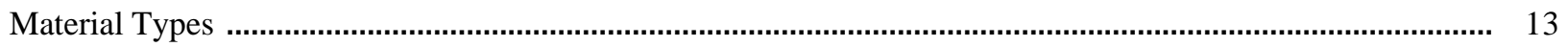

Method of Manufacture/Platform and Specimen Completeness .................................................................... 16

DC 1-2 (Hard Hammer Method): …...................................................................................................... 16

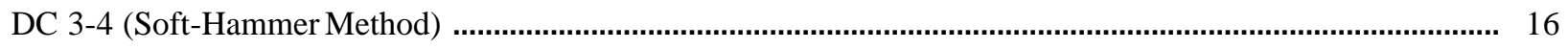

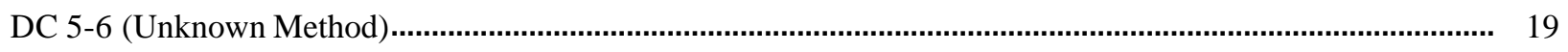

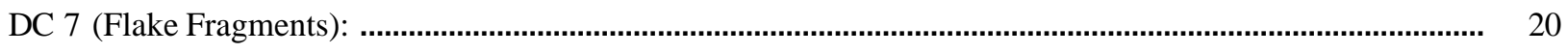

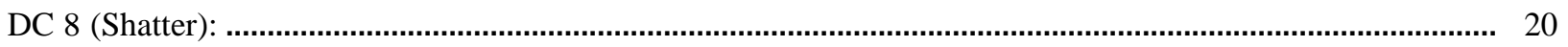

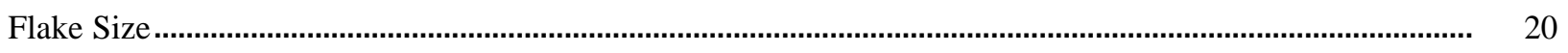

Cortex

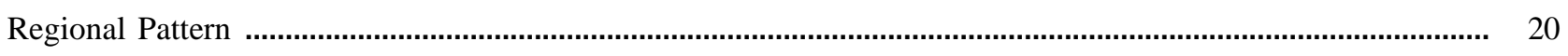

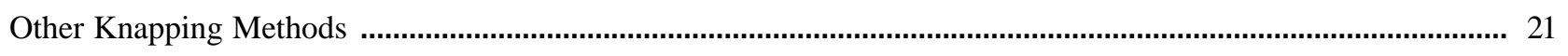

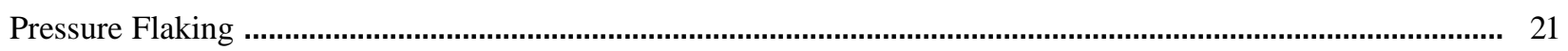

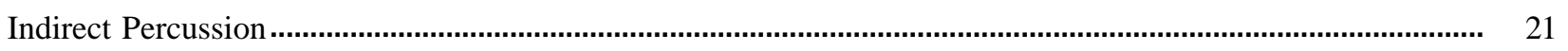

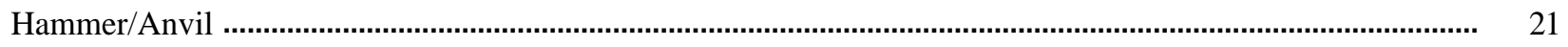

Stone Tools, Ceramics, Organic Materials and Ferriginous Sandstone …........................................................... 21

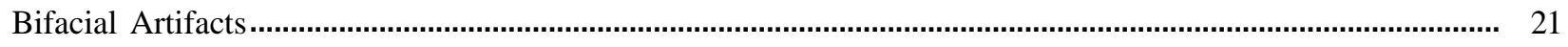

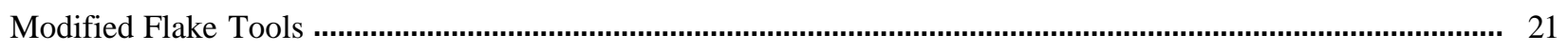

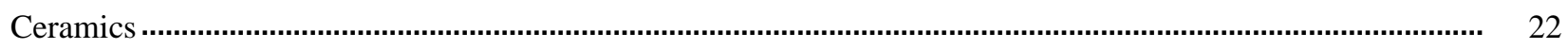

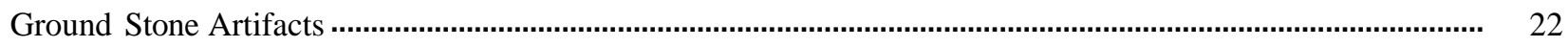

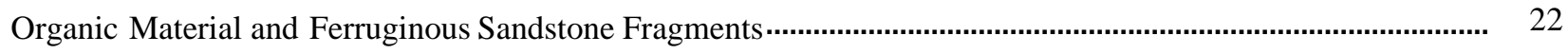

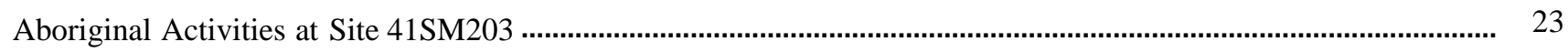

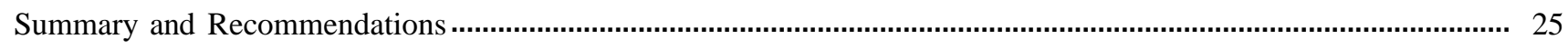

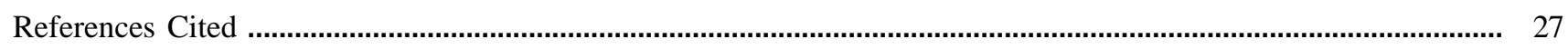




\section{List of Figures}

Figure 1. USGS topographic map of Site 41 SM203 and vicinity ............................................................................. 2

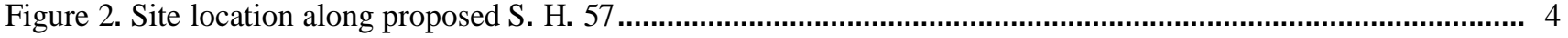

Figure 3. Excavation plan for 41SM203

Figure 4. Profile of North Wall. Gradall Trench 2. Area B .................................................................................. 12

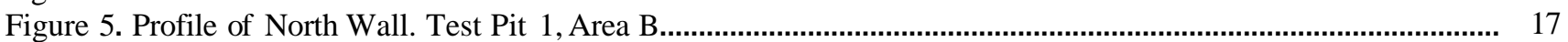

Figure 6. Profile of East Wall. Gradall Trench 6, Area A ....................................................................................... 18

Figure 7. Prehistoric Artifacts from 41SM203................................................................................................ 24

\section{LiST OF TABLES}

Table 1. Distribution of Lithic Debitage at 41SM203 _........................................................................................... 11

Table 2. Distribution of Chipped Stone and Ceramic Artifacts from 41SM203 …................................................... 14

Table 3. Lithic Debitage Categories from 41SM203 ........................................................................................ 15

Table 4. Distribution of Ground Stone Tools from 41SM203 ............................................................................. 19 


\title{
Management Summary
}

\begin{abstract}
Site 41SM203 is a prehistoric campsite situated along the southwesternoutskirts of the city of Tyler, Smith County, Texas. The site occupies the apex and lower slopes of a north-south trending ridge that runs for several miles. The lower part of the site lies relatively near springs located along the headwaters of Butler Creek. These springs or similar ones are thought to have been a major attraction of this locale, but significant cultural deposits were not found near them or in any part of the site subject to the investigation. The cultural materials that were found indicate sporadic and nonintensive use of the site through different parts of the Archaic period, particularly the Late Archaic. Following the Late Archaic, there is a gap in the cultural record caused by the apparent absence of the Early Ceramic period. Later, there is meager evidence of Late Prehistoric occupation in the way of Caddoan ceramics.
\end{abstract}




\section{INTRODUCTION}

Site 41SM203 lies partly within the right of way of the proposed extension of Grande Boulevard, also known as State Highway 57, in Smith County, Texas (Fig.1 \& 2). During a preliminary assessment of the proposed right of way in 1996, Jay Tullos of the Tyler District found prehistoric artifacts in disturbed and eroded areas along the ridge that contains much of site 41SM203. Then, in August of 1996, Tullos and Lance Marshall accompanied Glenn T. Goode on an archeological survey of the project. During this survey, shovel tests were dug that confirmed the presence of the site within the proposed right of way. These shovel tests indicated that the site had relatively deep sandy deposits in places, but nowhere were there found features or large concentrations of artifacts. However, enough materials were found, including three dart points and one potsherd, to recommend test excavations for the site.

The test excavations were carried out during the period of October 7 - 11, 1997. In addition to Tullos and Marshall, the following Tyler District personnel participated in the excavations: Robert Hall, Danny Scott (Gradall), Warren Tidmore, and Marlin Cooper (backhoe) of Mineola. These individuals are to be complimented for their contributions to the project.

Glenn T. Goode and Jesus Gonzalez of the Environmental Affairs Division supervised the operation. 
This Page Redacted Per THC Policy 


\section{Site Description AND ENVIRONMENTAL BaCKGROUND}

\section{Site Description}

The major part of site 41SM203 is situated along a high north-south trending ridge that is several miles long. On the western side, the slope of the ridge follows a gradual, then sharper, slope to the vicinity of the other important feature of the landscape, $250 \mathrm{~m}$ away. This is an area of springs that are part of the headwaters of Butler Creek. The creek is flanked on either side by the foot of the hill, which has a very gradual dip at this lower elevation. Along the bank of the narrow creek near the springs there are large pine, hardwood, and willow trees.

Eastward from the ridgetop the slope is much more gradual with the terrain leveling out into a broad upland plain. New-growth hardwood forest covers much of this area. Some of this forested area and the higher elevations along the ridge appear to have been cultivated until the 1960s or 1970s. The cultivation probably lasted for many years and the surface is still marked by apparent plow scars. Other, deeper, disturbance is in the form of sizeable holes created by burrowing animals. Along the ridgetop where the sand is deeper the only sizeable woody vegetation that has grown back in the last 15 or 20 years is pine.

Other modifications in the last half century include a sand/clay/gravel quarry to the north of the right of way. This activity may have removed a substantial portion of the site. Other impacts resulted from two county roads and an electrical station near their juncture (see Fig. 2).

Site 41SM203 is known to cover a large area of approximately $100 \mathrm{X} 400 \mathrm{~m}$, and is believed to cover (or to have covered) a much larger area; however, the site's precise margins were not found because it extends beyond the proposed right of way. Judging by the location and landform, the site could easily extend $100 \mathrm{~m}$ or more to both the north and south of the project area.

\section{Physiography and Geology}

The region of Texas that encompasses this project occurs within the West Gulf Coastal Plain Physiographic Province (Fenneman 1938). Rolling hills are a primary component of the landscape and in places are quite prominent. The terrain of Smith County is dissected by three rivers: the Neches, the Angelina, and the Sabine, and by numerous creeks such as the one (Butler Creek) that heads along the western margin of site 41SM203.
For the most part, flat areas are found only within the stream valleys, but there are occasional upland plains such as the one east of the site area.

The project area is underlain by the Sparta Sand of Eocene Age (Geologic Atlas of Texas). This formation consists primarily of massive deposits of quartz sand and clay, which may be locally carbonaceous or may contain fermginous sandstone. One deposit of this sandstone was found within the site area and similar depostis were exposed in a quarry north of the project area.

Other formations found in Smith County and the surrounding region are the Camzo, Reklaw, Queen City, and Weches formations. They are all of Eocene age, composed primarily of sands, clays, and ironstone, and sometimes occur as relatively narrow bands that are progressively younger toward the east.

\section{Climate, Paleoenvironment, AND Biota}

The region of eastern Texas that includes Smith County has a humid subtropical climate (Hatherly 1993). Prevailing winds from the south and southeast bring moist tropical air from the Gulf of Mexico, resulting in long, hot, and extremely humid summers; the average summer temperature is 80 degrees Farenheit. Winters are generally fairly mild and substantial snowfall is rare. Most freezing temperatures occur between November 7 and March 31. The average annual precipitation is 44 inches, most of which occurs from April through September.

Although the data are incomplete, the results of a recent study by Collins and Bousman (1993) indicate that the climate of this region often fluctuated during the late Pleistocene and Holocene periods. From pollen data taken from bogs, it has been inferred that the extent of grasslands and woodlands shifted in response to temperature and moisture. A forest community was present in the late Pleistocene. Then, with more xeric conditions during the early and middle Holocene, there was a return to grassland. During the late Holocene, more mesic conditions returned and oak-hickory forest replaced the grassland.

Central and southern Smith County and the vicinity of site 41SM203 are covered by oak-hickory-pine forest (Blair 1950). A typical plant community in the vicinity may have four layers, including an upper canopy and a closed lower canopy, but this network no longer exists 
This Page Redacted Per THC Policy 


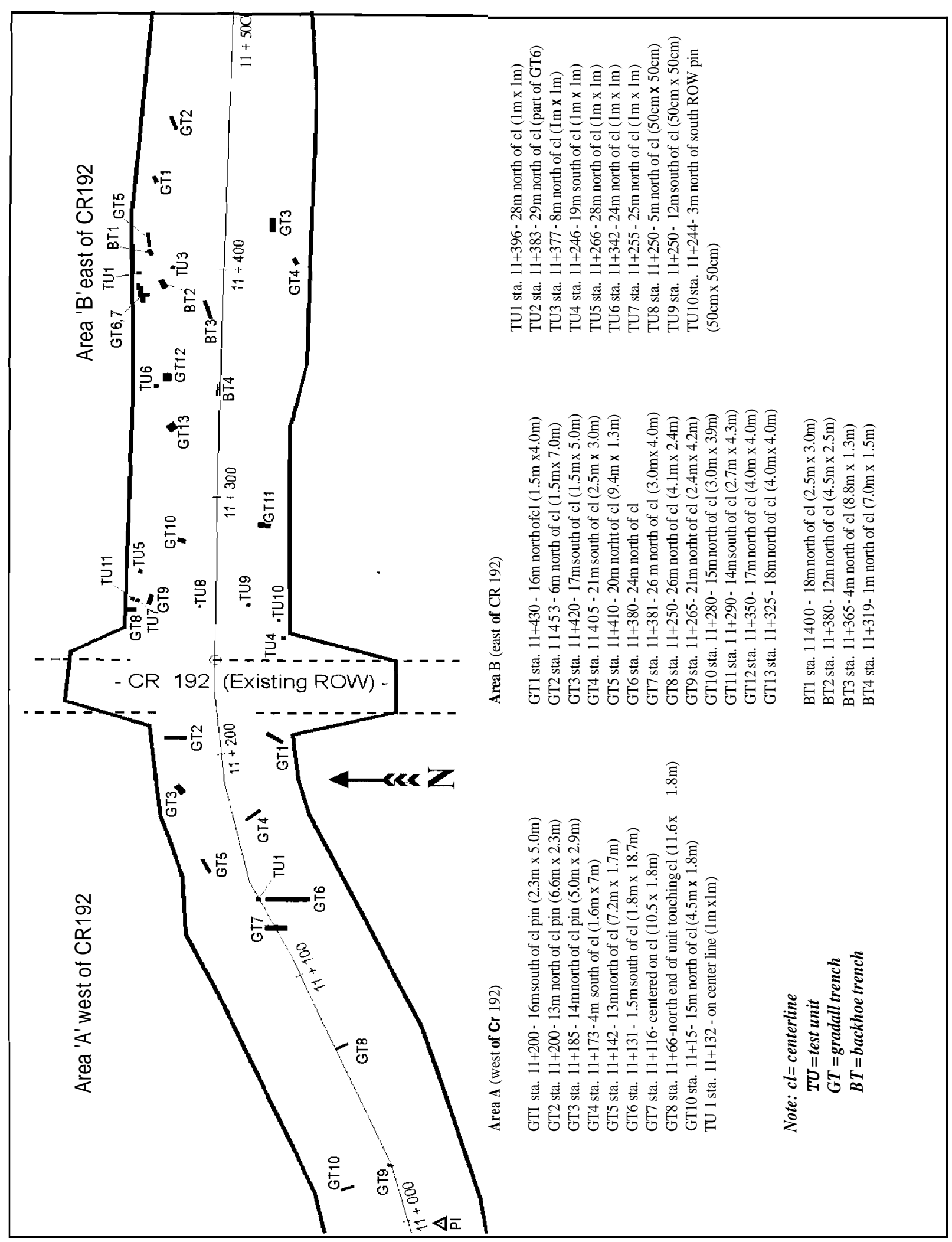

Figure 3. Excavation plan for 41SM203. 
upon the site due primarily to farming and ranching. Typical members of the upper canopy are shortleaf pine, loblolly pine, oak, hickory, and sweetgum. Depending on the location, the closed lower canopy may include sweetgum, postoak, hickory, and red maple, or water oak, white oak, and southern red oak. Diverse and abundant species fill out the understory, including dogwood, sassafras, and pawpaw. Among the various grasses, forbs, and vines on the site, bluestem, bullnettle, and dewberry were common.

Among the principal mammalian species that remain in the region, white-tailed deer, eastern cottontail, squirrel, raccoon, and striped skunk are common. Coyote and nine-banded armadillo also occur in the region.

Many species of birds inhabit the area, as do various snakes, turtles, frogs, and toads. 


\section{Archeological BACkground}

\section{Cultural Chronology}

Smith County is located toward the western side of the northeastern part of Texas. This is a region wherein many cultures settled or interacted through time. Early on, these hunting and gathering cultures were wide ranging, but as time passed band mobility decreased to the point that by the end of the Archaic period bands were settling into smaller temtories. This would untimately lead to semi-sedentism in the Early Ceramic Period.

Throughout time, though clearly more so at some times than others, the region shared a cultural identity with a much broader area encompassing parts of three neighboring states. Cultures along the western margin of northeastern Texas also interacted with others from the Post Oak Savannah and Black Land Prairie to the west, though perhaps to a lesser degree than with those to the east. Certainly during the Caddoan era this was the case.

The cultural chronology of the local area around Smith County and of the region as a whole has been segregated into five major components, long known as Paleoindian, Archaic, Early Ceramic, Caddoan (or Late Prehistoric or Neo-American), and Historic.

From the early part of the Paleoindian period there have been scattered finds of Clovis points, but Folsom points are rare. There have not been any excavations of components from this early period, but in at least one case a Clovis point was found associated with extinct megafauna. This was at the Murphey Site (41MR62), at Lake of the Pines, where a small Clovis point was found with mastodon bone (Forrest Murphey, personal communication).

During the latter part of the Paleoindian period, there was an increase both in the diversity and numbers of diagnostic flint tools. This is usually interpreted as an indication of both increased population and a loose form of temtoriality. Among the more important tools of this era are dart points (and sometimes knives) of the following types: Plainview/Meserve, San Patrice, Keithville Side-Notched, Dalton, Scottsbluff, and Big Sandy. More often than not, only one or two of these early types (and others) will be found at a site. However, there have been multiple finds of San Patrice or Keithville Side-Notched at a few sites in the central part of east Texas.

The Archaic period of the region is thought to have begun before 6000 B.C. and ended around 200 B.C. This long span of time is often divided into three subperiods known as the Early, Middle, and Late Archaic. As a general rule, the Archaic period is characterized by continued increase in population, decreased mobility, greater reliance on locally available lithic resources, certain different stone tools, and increased utilization of certain plant foods as evidenced by milling stones and stone hearths.

Because there is no clear break between the Paleoindian and Archaic periods, it is not known how long certain tools of the older period persisted into the new one. It is likely that certain forms such as Big Sandy and Keithville Side-Notched could reasonably be attributed to either period. Other bifacial tools such as Johnson, Wells, and Calf Creek clearly are later, but still from earlier part of the Archaic. Later still, a somewhat more diverse suite of projectile point types may have been in use during the Middle Archaic, but these are poorly known because no stratified sites have been excavated. Various straight-stemmed types such as M orrill and Bulverde are often attributed to the Middle Archaic, and it is possible that one of the most abundant Late Archaic types, Yarbrough, had its beginnings in this earlier time.

Compared to the earlier periods, the Late Archaic is better understood and its diagnostic tools are the most abundant of the region. Primarily, these are the Yarbrough, Gary, and Kent types of dart points. In keeping with the considerable interregional trade that was going on at this time, it is likely that many of the larger bifaces and caches of stone tools came into eastern Texas during the Late Archaic. This is the period best represented at the present site, 41SM203, as it is at many others across eastern Texas (and statewide). It is generally believed that the larger artifact assemblages and associated detritus of the Late Archaic period reflect a combination of significant changes in several aspects of aboriginal life, including increased population density, settlement pattern, resource exploitation, and group mobility (Perttula 1995, Story 1985).

With roots in the Late Archaic, the Early Ceramic Period is generally thought to have begun around 200 B.C., and to have been replaced about A.D. 800 by the Caddoan culture (Story 1990). In the northeastern portion of east Texas, mostly north of the Sabine River, the early ceramics are often called Williams Plain, are grog tempered, co-occur with Gary points, and may be linked to the Fouche Maline culture (Schambach 1982). To the south along the Neches and Angelina, and eastward, the early ceramics of the Mossy Grove tradition (Story 1990) 
have a sandy paste, and occur with Gary and Kent points. Eastward, within the middle Sabine drainage at the Resch Site (Webb 1969). were found the only two vessels of the Tchefuncte culture so far known, but Tchefuncte sherds are not common in east Texas. Also found at the Resch Site were ceramics of the later Marksville and Troyville cultures, which are usually better represented than Tchefuncte in this easternmost region near Louisiana. Toward the end of the Early Ceramic Period the mainly hunting and gathering societies were tending toward sedentism. A few earthen mounds and the burial practices at the Jonas Short site bespeak increased ritual behavior, but not necessarily ranked societies (Story 1990).

With the onset of the Caddoan culture around A.D. 800 came true sedentism and a more complex social and political system based on horticulture. Important cultural and material traits of the Caddoan period include ranked societies, ceremonial centers with earthern mounds, ritual burial, farming hamlets, distinctive ceramics, and imported stone artifacts. For analytical purposes, the Caddoan period has been divided variously into several subperiods, and there is not yet a concensus on which format to use. Apparently, the entire Caddoan area, which includes parts of adjoining states, participated in the Southern Cult (Krieger 1946) which involved earthern mounds, temples, and ritual mortuary practices, including immolation. The Historic Period of the Caddo began in the 16th century, and ended in the early 19th century with the removal of the people to Oklahoma.

\section{Previous Work}

The general area of central Smith County where site 41SM203 occurs has not seen a lot of archeological work, but a substantial amount has been conducted in the county as a whole, as well as in the surrounding region. The first excavation in the county was done in 1934 by A.T. Jackson (Guy 1990). This work occurred at the Howard Williams site (41SM8) which had occupations from the latter part of the Caddoan era.

Two decades later, in the 1950s, investigations in the region were sponsored by the River Basin Surveys. One of these, located southwest of the project area, was conducted at the proposed Blackburn Crossing Reservoir (Lake Palestine) in 1957 by LeRoy Johnson (Johnson
1958). Johnson found 35 prehistoric sites, 34 of which had Late Caddoan components. Another survey of this area was done in 1969 and 1970 by Southern Methodist University (Anderson 1971), during which 77 new sites were found. Later, test excavations at 10 of these sites revealed Archaic components at three sites, Early Caddo at three sites, and Late Caddo at all ten. A decade later, the Attaway Site was found eroding into Lake Palestine and test excavations were carried out by the Aggie Anthropological Society (Shafer 1981). This site is described as a Late Caddoan farming hamlet with a midden and small cemetery.

To the south of the project area in Cherokee County, the single most important excavation in the region was done at the George C. Davis Site (Story and Valastro 1977). Although there are earlier and later materials, the major component at the site is early Caddoan. Among the primary manifestations of that culture are earthen mounds of different form and function, and numerous house patterns. The site is particularly known for ritual mortuary practices, including immolation and elaborate grave goods, and for its long series of radiocarbon dates which is by far the best of the region.

North of the project area, other investigations of the region have been conducted along the upper Sabine drainage. At Lake Fork Reservoir, 130 prehistoric and historic sites were recorded in 1975 (Bruseth et al. 1977). Excavations here led to defining the Lone Oak, Pecan Grove, and Forest Hill phases of the Caddoan culture (Bruseth and Perttula 1981). Also in the upper Sabine basin, a survey was done by Gibson (1982) for the Big Sandy Creek Reservoir. Later, another survey of the area (Perttula et al. 1986) produced 75 sites, but only 32 prehistoric components were identified.

East of the project area, an archeological survey was conducted for the proposed Troup Mine (Scott et al. 1978). A total of 17 sites were found, 16 of which are prehistoric. Later, at Troup Mine an additional 248 sites were recorded (Skinner 1981), 46 of which were prehistoric. Thirty-three sites had Archaic components, and a wide range of Caddoan materials was found.

One of the most recent investigations in Smith County was conducted by the Texas Parks and Wildlife Department (Howard 1996). The six sites found all are historic, with one also having a Late Caddoan component. 


\section{Excavation Procedures, Soils And Anomalies}

\section{Excavation Procedures}

When this project was surveyed in August 1996, rough margins of the site within the right of way were found by shovel testing. These small tests revealed that the depth of the generally sandy deposit covering the site varied considerably according to changes in the landform. The deposit was much deeper, in excess of 150 $\mathrm{cm}$, along a high ridge in the vicinity of centerline station $11+350$ and $11+400$ (see Fig. 2). At lower elevations nearer the creek, around centerline station $11+150$, the sand was only about $40 \mathrm{~cm}$ deep.

Artifacts were recovered from all shovel tests, but seemed to be somewhat more numerous at the ridge top along the north right of way. Based on these findings, an excavation plan was devised that could be carried out within about two weeks. Typically, the placement of some excavation units was predicated on the initial findings. The remainder were placed as needed to fill in the gaps and not leave any extremely large areas untested.

Site 41SM203 has been divided artificially by County Road (CR) 192, so the area west of the road was called Area A, and the eastern side was called Area B. Area A was tested with a single $1 \mathrm{X} 1 \mathrm{~m}$ test pit (TP) and 10 gradall trenches (GT), while Area B was tested with 11 test pits ( 8 of 1 X $1 \mathrm{~m}$ and 3 of 0.5 X $0.5 \mathrm{~m}$ size), 14 gradall trenches, and 4 backhoe trenches (BT). The total number of excavations, then, was 12 hand-dug test pits and 24 machine-dug trenches (Fig. 3). This scope of work was based on, and exceeded, a testing plan approved by the Texas Historical Commission.

The test pits were dug according to standard excavation procedures, which included $10 \mathrm{~cm}$ excavation increments (levels), screening through $114 \mathrm{in.} \mathrm{hardware}$ cloth, and placing artifacts in labeled bags. For this work, the usual complement of tools was used, including shovels, trowels, brushes, and smaller tools. The floors of individual levels were usually sufficiently cleaned to allow the detection of features, but only natural anomalies such as rodent burrows and stumplroot stains were observed. None of these kinds of anomalies required sustained examination; however, one anomaly was investigated at length. This was a very large (larger than $4 \times 7 \mathrm{~m}$ ) concentration of ferruginous sandstone rocks that occurred along and extended beyond the north right of way in the area of TP 2 and GT 6 (see discussion below).
At first, a gradall was used to dig the large exposures and trenches. The operator did a good job of making cuts of 10 to $15 \mathrm{~cm}$ thickness and maintaining straight walls, but the deep and loose sand created problems. With depth, the walls of trenches caved in, and it was usually impossible to remove this dirt. Furthermore, at the apex of the ridge where the sand was deepest and softest the gradall was unable to maneuver. It was then necessary to bring in a backhoe but, except for maneuverability, it is generally an inferior machine and the results were less satisfactory. Because the backhoe worked much slower, we were not able to dig as many trenches (or trenches of large size in some places) as would have been possible with the gradall.

It should be emphasized that the total excavation at the site, 36 exposures of various sizes, opened only a small fraction of the site's total area.

\section{SoILS}

Site 41SM203 lies within an area of the WolfpenPickton Association (Hatherly 1993) where three soils have been mapped. Pickton soils (Grossarenic Paleudalfs) are loamy fine sands (1-6\% slopes) that occur on broad interstream divides such as the ridge where site 41SM203 is located. The Tenaha loamy fine sand (Arenic Hapludults), with 8-20\% slopes, occur on the uplands along and above drainageways. The Cuthbert fine sandy loam (Typic Hapludults), with 5-20\% slopes, occurs on moderately to strongly sloping upland surfaces, especially along the breaks of drainageways.

The sandy deposit exposed by excavation at the site ranged considerably in content and depth. In Area B, beginning along the eastern flank of the ridge, the deposit is upwards of $2 \mathrm{~m}$ in depth (Fig. 4), with a maximum depth of $240 \mathrm{~cm}$ attained in GT 1 . This deep deposit continued westward for approximately $75 \mathrm{~m}$. The profile is characterized by a light brown sandy loam, up to 120 $\mathrm{cm}$ deep, which is underlain by a pale brown loamy sand up to $70 \mathrm{~cm}$ in thickness, which in turn is underlain by a reddish brown loamy sand or a creamy white sand. These latter deposits are up to $50 \mathrm{~cm}$ in thickness and are underlain by an orange sandy clay substrate.

In this area of deep sandy deposits there are numerous thin lenses of orange clay, mostly 2 to $5 \mathrm{~mm}$ thick and spaced about $12 \mathrm{~cm}$ apart, that begin around 75 $\mathrm{cm}$ below ground surface and continue to the clay substrate in some places.

From a depth of $200 \mathrm{~cm}$ in TP 3 and $150 \mathrm{~cm}$ in TP 1 (Fig. 5), the sandy deposit gradually becomes shallower 
moving down the slope to the west. The maximum depth at TP 7 was $110 \mathrm{~cm}$. In this area, the profile consists of an overlying grayish brown sandy loam, which is underlain by a light reddish brown sandy loam that occasionally had thin lenses of clay. The creamy white sand does not occur in this part of the site, but the substrate is the same orange sandy clay.

At the eastern side of Area A (starting at the CR 192 fenceline), the same profile continued, then gradually decreased in thickness moving to the west. In and around TP 1 and GT 6 (Fig. 6) of Area A, the sandy deposit was only $50 \mathrm{~cm}$ deep. An upper grayish brown sandy loam (A horizon) was underlain by light reddish to yellowish brown loamy sand (B/B thorizon), over a substrate of yellow and orange clay (2 Bt horizon).

The sandy mantle covering this portion of the state poses many problems for archeologists, geomorphologists, and soil scientists (Fields 1990, Collins and Bousman 1993, Perttula et al. 1993, J. Abbott, personal communication). Of these problems, the primary ones concern the origin and age of the sandy deposits and how cultural activities and materials influenced or can be explained by sediments and soil development. According to Abbott, there are three primary hypotheses to explain the origin of the sometimes thick east Texas sands: 1) the biomantle hypothesis (a biological process) in which sediments are moved to the surface by organisms, 2) the aeolian hypothesis, and 3) the colluvial hypothesis. Additionally, all three processes may have figured in creating a particular profile.

Based on available information, there are no clear indicators at site 41SM203 to address these problems (although the site was not inspected by a geomorphologist). The profiles are entirely typical of the region, both the shallow and the deep ones. Generally speaking, the profiles consist of an A horizon of light brown loamy sand, a B1 - B3 horizon of light yellowish brown to reddish brown sandy loam containing thin (1 $\mathrm{cm}$ ) clay lamellae, and a $\mathrm{C}$ horizon of bleached white sand sometimes containing clay lamellae, all overlying a yellowish orange sandy clay substate which is a $2 \mathrm{Bt}$ horizon. Because features such as these of the $\mathrm{B}$ and $\mathrm{C}$ horizons can potentially develop over a comparatively short period of time, there is no way to determine whether or not the sandy deposits are ancient.

At this site the cultural materials were not helpful in addressing these problems, or in providing information beyond a very general picture of the time and way the site was used. Diagnostic artifacts from the major time of occupation, the Late Archaic, were few (six) and scattered from depths of $20-120 \mathrm{~cm}$ within the sand. A single earlier dart point was found and only seven potsherds were recovered. There were no discrete or distinctive cultural lenses and no cultural features were uncovered. It is reasonable to infer that at site 41SM203 a sandy mantle has been in place on the high ridge and its slopes for a long expanse of time, but there was comparatively little human use of the area until the late Holocene. It is also reasonable to infer that the three processes mentioned above may have contributed in varying degrees to the present profile. Determining what those roles may have been would require a considerable amount of focused geomorphic research (Abbott, personal communication).

\section{Anomalies}

No cultural features were found at 41SM203 despite the digging of a fairly large number of machine and hand units. The only anomaly that was investigated to any extent was a large deposit of fermginous sandstone. When first encountered in a 1 X $1 \mathrm{~m}$ test pit, a small part of this anomaly was thought to possibly be a cultural feature. However, from its original exposure in TP 2, it continued to expand and the gradall was finally called in to fully expose it. This was accomplished only within the right of way because the anomaly extended northward onto private property. The part exposed was roughly 7-m long and 4-m wide. This bed of sandstone varied in size from small boulders down to pea-gravel size, there being thousands of the latter. None of the rocks appeared to have been artificially modified, thus it was concluded that the sandstone was a natural deposit. Similar fermginous sandstone was also exposed within a quarry north of the right of way.

The other anomalies observed at the site were also of natural origin. These included numerous root and stump stains and animal burrows both large and small. An area of large, active burrows is in the vicinity of TP 3 .

The artifacts collected from 41SM203 were distributed in low to moderate numbers across an area of approximately $50 \times 400 \mathrm{~m}$. This is the area of the proposed right of way that bisects the site, and does not necessarily provide a representative sample of the site's contents. Only one area, the vicinity of TP 1, 2, 3, and 4, had what might be considered to be significant amounts of artifacts, and even there they occurred for the most part in very small numbers per excavation level. More importantly, the artifacts could not be linked to one another, or to cultural features, because the site lacked discrete components and features. 
Table 1. Distribution of lithic debitage at 41SM203

\begin{tabular}{|c|c|c|c|c|c|c|c|c|c|c|c|c|c|c|}
\hline & & & & & & & UNITS & & & & & & & \\
\hline Level & TP1-A & TP1 & TP2 & TP3 & TP4 & TP5 & TP6 & TP7 & TP8 & TP9 & TP10 & TP11 & TP12 & Total \\
\hline 1 & 4 & 9 & 7 & 0 & 6 & 4 & 2 & 0 & 1 & 0 & 0 & 0 & 0 & 33 \\
\hline 2 & 4 & 19 & 12 & 1 & 11 & 2 & 2 & 3 & 0 & 0 & 2 & 1 & 0 & 57 \\
\hline 3 & 7 & 8 & 9 & 1 & 8 & 2 & 3 & 6 & 1 & 0 & 3 & 5 & 0 & 53 \\
\hline 4 & 3 & 10 & 19 & 4 & 20 & 6 & 4 & 4 & 1 & 0 & 2 & 3 & 0 & 76 \\
\hline 5 & 0 & 12 & 18 & 2 & 19 & 4 & 1 & 2 & 1 & 0 & 0 & 0 & 0 & 59 \\
\hline 6 & & 10 & 0 & 4 & 23 & 2 & 3 & 4 & 0 & 1 & & & 0 & 47 \\
\hline 7 & & 17 & & 0 & 6 & 3 & 0 & 3 & & 0 & & & 8 & 37 \\
\hline 8 & & 5 & & 0 & & 3 & 2 & 2 & & & & & & 12 \\
\hline 9 & & 10 & & 2 & & 0 & 1 & 3 & & & & & & 16 \\
\hline 10 & & 4 & & 3 & & & 0 & 1 & & & & & & 8 \\
\hline 11 & & 8 & & 3 & & & & 0 & & & & & & 11 \\
\hline 12 & & 6 & & 7 & & & & & & & & & & 13 \\
\hline 13 & & 3 & & 2 & & & & & & & & & & 5 \\
\hline 14 & & 1 & & 3 & & & & & & & & & & 4 \\
\hline 15 & & 0 & & 5 & & & & & & & & & & 5 \\
\hline 16 & & & & 2 & & & & & & & & & & 2 \\
\hline 17 & & & & 1 & & & & & & & & & & 1 \\
\hline 18 & & & & 1 & & & & & & & & & & 1 \\
\hline $\mathrm{T}=440$ & 18 & 122 & 65 & 41 & 93 & 26 & 18 & 28 & 4 & 1 & 7 & 9 & 8 & 440 \\
\hline
\end{tabular}




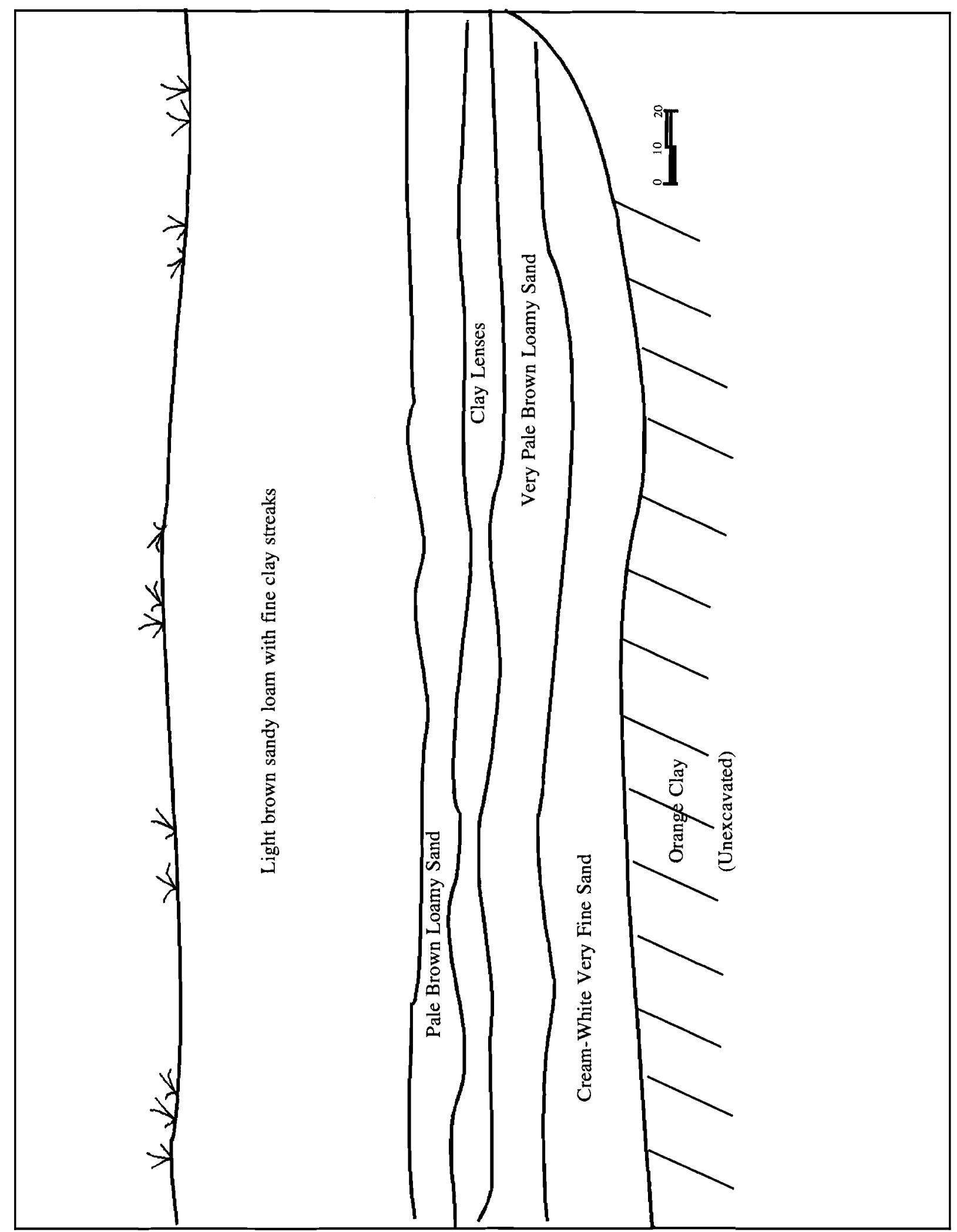

Figure 4. Profile of north wall, gradall trench 2, Area B. 


\section{Artifact Assemblage}

The artifact assemblage consists of 3 dart points, 1 dart point fragment, 4 small bifacial fragments, 6 small ceramic sherds, 14 specimens of ground stone, and 440 pieces of lithic debitage. Although the small collection of diagnostic artifacts is perhaps the most significant part of the assemblage, for its usefulness in pinpointing the times of major occupation, the debitage sample also contributes to understanding cultual processes of the region.

\section{Horizontal and Vertical Distribution of Artifacts}

\section{Lithic Debitage}

From a dozen test pits (TP), a total of 440 flakes (Table 1) were recovered from the site. Flakes were found in every test pit, but two pits, TP 8 \& TP 9 (50 X $50 \mathrm{~cm}$ ), produced a total of only 5 flakes. The most productive units are TP 1, 2,3, and 4, all located along the ridgetop in the vicinity of centerline station $11+300$. Together they account for 321 pieces of debitage, or $73 \%$ of the total. Two of these units, TP 1 and TP 4, produced almost half of the total debitage. Of these four units, TP 3 was the deepest at $200 \mathrm{~cm}$, but it had the fewest artifacts with only 41 specimens; thus, its average per level is quite low. As a rule, the debitage count per level is very low, and there does not appear to be much in the way of meaningful vertical distribution patterns. In some of the shallower units $(60-70 \mathrm{~cm})$, the largest artifact samples were toward the bottom, while in one of the two deep units $(150-200 \mathrm{~cm})$ the most productive levels were above $80 \mathrm{~cm}$. However, in the other deep unit (TP 3 ) they were below $110 \mathrm{~cm}$. Only 6 levels at the site had as many as 18 specimens, the greatest number for a level being 23 .

\section{Stone Tools and Ceramics}

Like the debitage, a majority of the tools (Table 2) also came from the ridgetop, this being especially true of the ground stone implements (Table 4). All the classes of tools found on the ridgetop were scattered in low numbers across the remainder of the site. The one artifact class found elsewhere but missing from the ridgetop is ceramics. The minute sample of brushed and plain sherds came from a small area (TP 7/11) along the north rightof-way, $100 \mathrm{~m}$ downslope from the ridgetop.

Mainly due to the lack of ceramics and arrowpoints on the ridgetop, but partly owing to the propensity of Archaic peoples for these landforms, it is reasonable to infer that the occupations there were largely, perhaps wholly, of the Archaic era. The conclusion, then, would be that the ridgetop was little used after Archaic times. This can also be said for all of the area within the proposed right-of-way because there was a general dearth of ceramics, and no arrowpoints at all were found.

\section{Debitage Analysis}

This analysis of lithic debitage is concerned with the standard aspects of lithic debris, using a group of primary variables and three secondary variables. The primary variables deal mainly with learning about material types and sources, manufacturing methods, and tool types. These variables are: 1) material type, 2) specimen size, 3) specimen completeness, 4) method of manufacture/ platform, and 5) presence of cortex. The secondary variables concern postmanufacturing modification of three kinds: 1) thermal modification, (2) patination, and (3) use modification.

\section{Material Types}

The study of material types from a site can be a very productive exercise. Generally, such a study is intended to answer questions about several interrelated factors of an assemblage, including: 1) the kinds and amounts of local materials, 2) the kinds and amounts of nonlocal materials, 3) the sources of both classes, and 4) the possible circumstances under which materials came to the site. If answers can be provided for questions about these factors, then it may be possible make meaningful inferences about larger problems such as band mobility, territoriality, and exchange systems.

The northeastern Texas region is known for being generally poor in siliceous raw materials. To make up for this, the native populations frequently imported goodquality materials from many directions. In most cases, it appears that the closest good materials were the ones most commonly used, as would be expected. So it is that sites such as 41SM203, situated toward the western margin of the region, will show a dependency on sources from the west while sites more to the northeast imported stone from that direction.

In the case of 41SM203, and with most sites of the region, there can be no precise quantification of local versus nonlocal materials nor precise sourcing of the 
Table 2. Distribution of chipped stone and ceramic artifacts from 41SM203

\begin{tabular}{|c|c|c|c|c|c|c|c|c|c|c|c|}
\hline \multicolumn{12}{|c|}{ UNITS } \\
\hline Level & TP1-A & TP-1 & TP-2 & TP-3 & TP-4 & TP-5 & TP-7 & TP-9 & TP-10 & TP-11 & Total \\
\hline 1 & & & TF & & & & & & & & 1 \\
\hline 2 & & & & & TF & $\mathrm{BF}$ & & & & $2 S$ & 4 \\
\hline 3 & $\mathrm{D}, \mathrm{TF}$ & & $\mathrm{BF}$ & & & & 35 & & MF & $s$ & 8 \\
\hline 4 & TF & & & & BF, TF & & $\mathrm{S}$ & & & & 4 \\
\hline 5 & & & $\mathrm{CF}, \mathrm{TF}$ & & & $\mathrm{BF}$ & & & & & 3 \\
\hline 6 & & & & & & & & TF & & & 1 \\
\hline 7 & & $D$ & & & & & MF & & & & 2 \\
\hline 8 & & & & & & & & & & & 0 \\
\hline 9 & & TF & & & & & & & & & 1 \\
\hline 10 & & & & & & & & & & & 0 \\
\hline 11 & & D & & & & & & & & & 1 \\
\hline 12 & & & & $\mathrm{MF}, \mathrm{BF}$ & & & & & & & 2 \\
\hline Total & 3 & 3 & 4 & 2 & 3 & 2 & 5 & 1 & 1 & 3 & 27 \\
\hline Legend: & & & $\begin{array}{l}\text { BF- } \\
\text { TF- }\end{array}$ & $\begin{array}{l}\text { ace Fragme } \\
\text { amed Flak }\end{array}$ & & $\begin{array}{l}\text { MF-Mod } \\
\text { CFCore }\end{array}$ & $\begin{array}{l}\text { Flake } \\
\text { gment }\end{array}$ & & & & \\
\hline
\end{tabular}

nonlocal stone for two reasons: 1) in many areas the local materials have not been identified with any precision, and 2) many materials are not sufficiently distinctive as to their source. Thus, it is generally understood that approximations are the rule, and there will usually be some error factor to consider. This is how the analysis of material types from 41SM203 should be viewed.

The first aspect of the 41SM203 assemblage that stands out is that it is composed largely of various flints and cherts. From a total of 414 specimens of debitage out of a grand total of 440 checked for material type, the following percentages were recognized: 1) flint - 90\%, 2) fine-grained quartzite (sometimes called Potter chert) $4.8 \%, 3$ ) silicified wood $-3.4 \%, 4$ ) quartzite - $0.9 \%, 5$ ) chalcedony $-0.5 \%$, and 6 ) ferruginous sandstone $-0.4 \%$.

Looking first at the flint, two main color groups are present that are usually called gray and tan (light brown). Each group has several variations based partly on mixed colors and inclusions, and a number of sources are indicated. The tan group is the largest by far with almost
200 specimens; the gray group has about 80 pieces. Since these are the most common materials, it is probable that some were available locally and known sources of some are not that distant.

A relatively small number of flakes in the assemblage retain cortex. Some of this cortex, mostly on the tan flint, is the hard and thin kind typical of upland gravels that occur in this region of the Neches drainage. Similar gravels also occur in many other places, such as the Trinity drainage farther west and in the drainages northeast of the project area.

Although a certain percentage, perhaps most, of the tan flint is thought to be local, the second most common variety of tan flint is more likely to be from nonlocal sources. Some of the gray material might also be from the local area, but the most common variety of it is almost certainly from farther away. These gray and tan materials of probable nonlocal origin closely resemble flints of the Bell-Coryell county region, which have been found in the Jewett Mine area (Fields 1990) of Freestone 
and Leon counties southwest of the project area.

The evidence for the origin of at least some of the tan flint comes from a survey of the Lake Palestine area (Anderson 1972) to the southwest. There, tan flint, quartzite, and silicified wood were found in Pleistocene gravels on the low slopes east of the Neches river. The artifacts from this survey reveal an interesting dichotomy in material types, apparently influenced somehow by the presence of the river.

Tan flint artifacts were found on both sides of the Neches River. The largest number - 784, or $53.5 \%$ of the debitage total - came from the west side, but the smaller number - 560 - on the east side was a greater percentage (76.3\%) of the east side's total. In other words, $76.3 \%$ of the east side total was tan flint, while on the west side tan flint accounted for $53.5 \%$ of the sample.

Also, higher proportions of early stage flakes came from the east side, which matches the finding of tan flint sources there. Tan flint was represented in all kinds and stages of the debris, including cores, as well as in the tool assemblage.

The pattern for the gray flint was the same on one count, but the opposite on the other. That is, both the greater number and the greater proportion of gray flint came from the west side. On the west side, the 231 specimens are $15.7 \%$ of the total, while from the east side the 72 specimens are $10.6 \%$ of the total. This would seem to suggest that the gray flint was coming from the west, which goes hand-in-hand with the fact that no sources of gray, blue gray, or spotted gray flint were

Table 3. Lithic debitage categories from 41SM203

\begin{tabular}{|c|c|c|c|c|c|c|c|c|c|c|c|c|c|c|}
\hline \multicolumn{15}{|c|}{ UNITS } \\
\hline \multicolumn{15}{|l|}{ Debitage } \\
\hline Category & TPI-A & TP1 & TP2 & TP3 & TP4 & TP5 & TP6 & TP7 & TP8 & TP9 & TP10 & TP11 & TP12 & Total \\
\hline $\mathrm{DC} 1$ & 0 & 2 & 1 & 1 & 0 & 0 & 0 & 0 & 0 & 0 & 0 & 0 & 0 & 4 \\
\hline $\mathrm{DC} 2$ & 0 & 1 & 0 & 0 & 0 & 0 & 4 & 0 & 0 & 0 & 0 & 0 & 1 & 2 \\
\hline DC3 & 1 & 18 & 13 & 7 & 15 & 7 & 7 & 10 & 0 & 1 & 3 & 2 & 2 & 83 \\
\hline $\mathrm{DC4}$ & 5 & 30 & 15 & 9 & 24 & 6 & 1 & 4 & 2 & 0 & 3 & 2 & 2 & 109 \\
\hline DC5 & 0 & 7 & 0 & 0 & 6 & 3 & 0 & 1 & 0 & 0 & 0 & 0 & 0 & 18 \\
\hline DC6 & 1 & 5 & 0 & 2 & 2 & 0 & 6 & 1 & 0 & 0 & 0 & 0 & 0 & 11 \\
\hline$D C 7$ & 6 & 58 & 36 & 22 & 46 & 10 & 0 & 12 & 2 & 0 & 1 & 5 & 3 & 207 \\
\hline DC8 & 5 & 1 & 0 & 0 & 0 & 0 & & 0 & 0 & 0 & 0 & 0 & 0 & 6 \\
\hline Total & 18 & 122 & 65 & 41 & 93 & 26 & 18 & 28 & 4 & 1 & 7 & 9 & 8 & 440 \\
\hline$c x$ & 3 & 27 & 11 & 4 & 12 & 0 & 1 & 2 & 0 & 0 & 2 & 0 & 2 & 64 \\
\hline BRN & 3 & 20 & 19 & 8 & 22 & 1 & 3 & 2 & 0 & 0 & 1 & 1 & 0 & 80 \\
\hline PAT & 0 & 3 & $\underline{0}$ & 0 & 0 & 0 & 0 & 0 & 0 & 0 & 0 & 0 & 0 & 3 \\
\hline $20-30 \mathrm{~mm}$ & 3 & 7 & 6 & 5 & 8 & 2 & 3 & 3 & 1 & 1 & 1 & 0 & 0 & 40 \\
\hline $30-40 \mathrm{~mm}$ & 1 & 0 & 1 & 0 & 0 & 0 & 0 & 2 & 0 & 0 & 1 & 0 & 0 & 5 \\
\hline $40-50 \mathrm{~mm}$ & 0 & 0 & 1 & 1 & 0 & 0 & 0 & 0 & 0 & 0 & 0 & 0 & 0 & 2 \\
\hline Legend: & & $\begin{array}{l}\text { DC1-Ha } \\
\text { DC2-He } \\
\text { DC3-S } \\
\text { DC4-S }\end{array}$ & Hamme & $\begin{array}{l}\text { Comp } \\
\text { Coragm } \\
\text { Compl } \\
\text { Fragm }\end{array}$ & & & $\begin{array}{l}\text { Unkno } \\
\text { Unkno } \\
\text { FlakeF } \\
\text { Shatte }\end{array}$ & $\begin{array}{l}\text {,Comp } \\
\text {,Fragn } \\
\text { gment. }\end{array}$ & & $\begin{array}{l}\text { CX-Cort } \\
\text { ERN-Bur } \\
\text { PAT-Pat }\end{array}$ & ad & & & \\
\hline
\end{tabular}


found locally. From the Lake Palestine survey it was also learned that gray flint was used more during the Archaic and little, if at all, by later peoples. No arrowpoints of gray flint were found. Another interesting finding regarding arrowpoints is that all of those west of the river were of fine-grained quartzite, but on the east side they were predominately of tan flint.

The other materials found on this survey (Anderson 1972), fine-grained quartzite and silicified wood, also exhibit notable differences from one side of the Neches River to the other. Both are more abundant and in higher proportions on the west side of the river.

In addition to the previously described gray flint in the site 41SM203 assemblage, there is also a small amount of the glassy, translucent gray flint common in central Texas north of Austin. There is also a small percentage of other translucent materials that could have nonlocal origins. Two such specimens appear to be chalcedony and could also be from fairly distant sources.

After flint, the most abundant material is finegrained quartzite, but it accounts for only $4.8 \%$ of the assemblage. This material is much more abundant to the north, northwest, and west of Smith County, sometimes being the primary stone at a site.

From the survey of Lake Palestine (Anderson 1972), it was learned that fine-grained quartzite was used much more during the Late Prehistoric than during the Archaic. The finding at this site of a preponderance of flint and no arrowpoints may be further evidence of greater Late Prehistoric reliance on local resources. Clearly, and for good reason, it was flint that was most often brought into the locale of site 41SM203. That certain Early Ceramic and Caddo peoples used more of the locally available stone has been cited as evidence of more restricted territoriality during the Late Prehistoric (Anderson 1972).

Next in abundance at 41SM203 is silicified wood, making up $3.4 \%$ of the collection. Silicified wood is found over a wide expanse of east Texas, being generally more abundant to the east and southeast of Smith County. There are two other material types from the site which, like chalcedony, are barely represented, but this is because they are of such poor quality. There are four flakes of coarse-grained quartzite and two flakes of ferruginous sandstone. Both materials are widely distributed across the region, but were not ordinarily used to make chipped stone tools.

\section{Method of Manufacture/Platform and SPECIMEN COMPLETENESS}

The other variables of the debitage analysis deal mainly with learning what kinds of tools were made and refurbished at 41SM203, and how they were made. The scheme used for this analysis involves separating the debitage into eight categories (DC 1-8) based on either characteristics of flake platforms or on having no platform at all, and on whether or not a specimen is complete. Six of the eight debitage categories are thus a combination of two primary variables, method of manufacture and platform type, along with completeness. Then, the last two variables deal with fragments that lack platforms. After describing each of the categories, the discussion will turn to how the other primary variables, and the secondary variables, are related to them.

The eight debitage categories (Table 3) are: DC 1 (hard hammer complete, DC 2 (hard hammer fragmentary), DC 3 (soft hammer complete), DC 4 (soft hammer fragmentary), DC 5 (unknown method complete), DC 6 (unknown method fragmentary); DC 7 (flake fragment), and DC 8 (shatter). The data from this analysis are presented with the following caveat: When classifying flakes as either hard hammer, soft hammer, or made by some other method, it should be understood that these figures are approximations, presented with the belief that they may be correct about $90 \%$ of the time. Flakes are classified one way or another depending on a combination of features, but certain features can be produced in different ways. Thus, there is overlap between the debris of different flaking methods making it impossible to accurately categorize all the debitage of a particular assemblage.

\section{1-2 (Hard Hammer Method):}

At this site the hard hammer method is barely represented with only six specimens. This sample is so small that it precludes saying anything definitive about hard-hammer reduction. Of the several possible reasons for this low figure, it seems most likely that the kind (including form/size) and amount of material available were the overriding factors, as is usually the case. There simply must not have been any substantial stone supply nearby. If there had been, then there should be numerous hard-hammer flakes and shatter, both with cortex, from the early-stage reduction of generally small resources.

In sum, no evidence was found at this site that the hard-hammer method was used to any degree to reduce cores into flake or blade tools, or into bifacial blanks for use as dart points, knives, or gouges. Such evidence might still exist somewhere else on this large site, however.

\section{3-4 (Soft-Hammer MethoD)}

In sharp contrast to the meager number of hardhammer flakes, the soft-hammer categories (192 


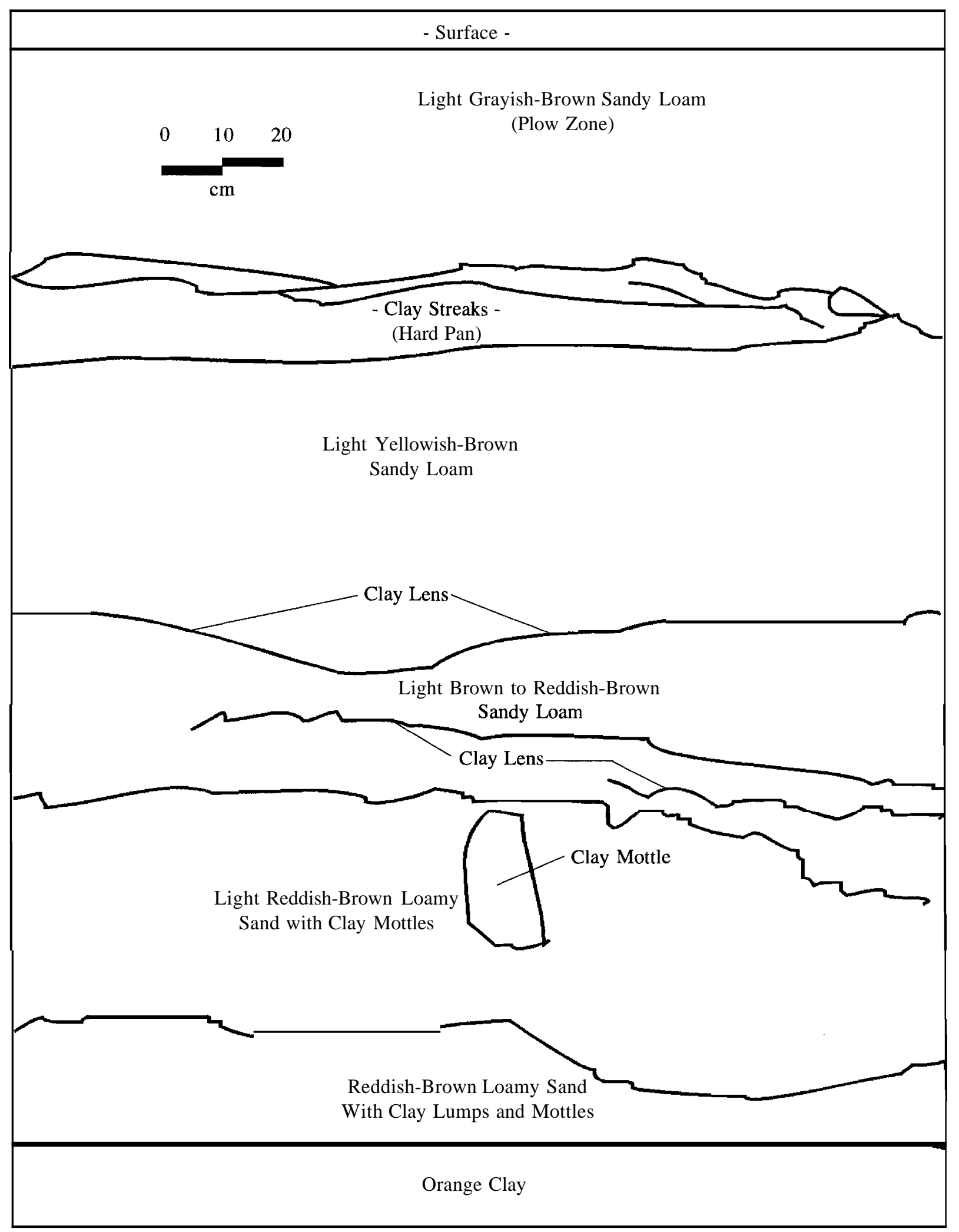

Figure 5. Profile of north wall, test pit 1, Area B. 


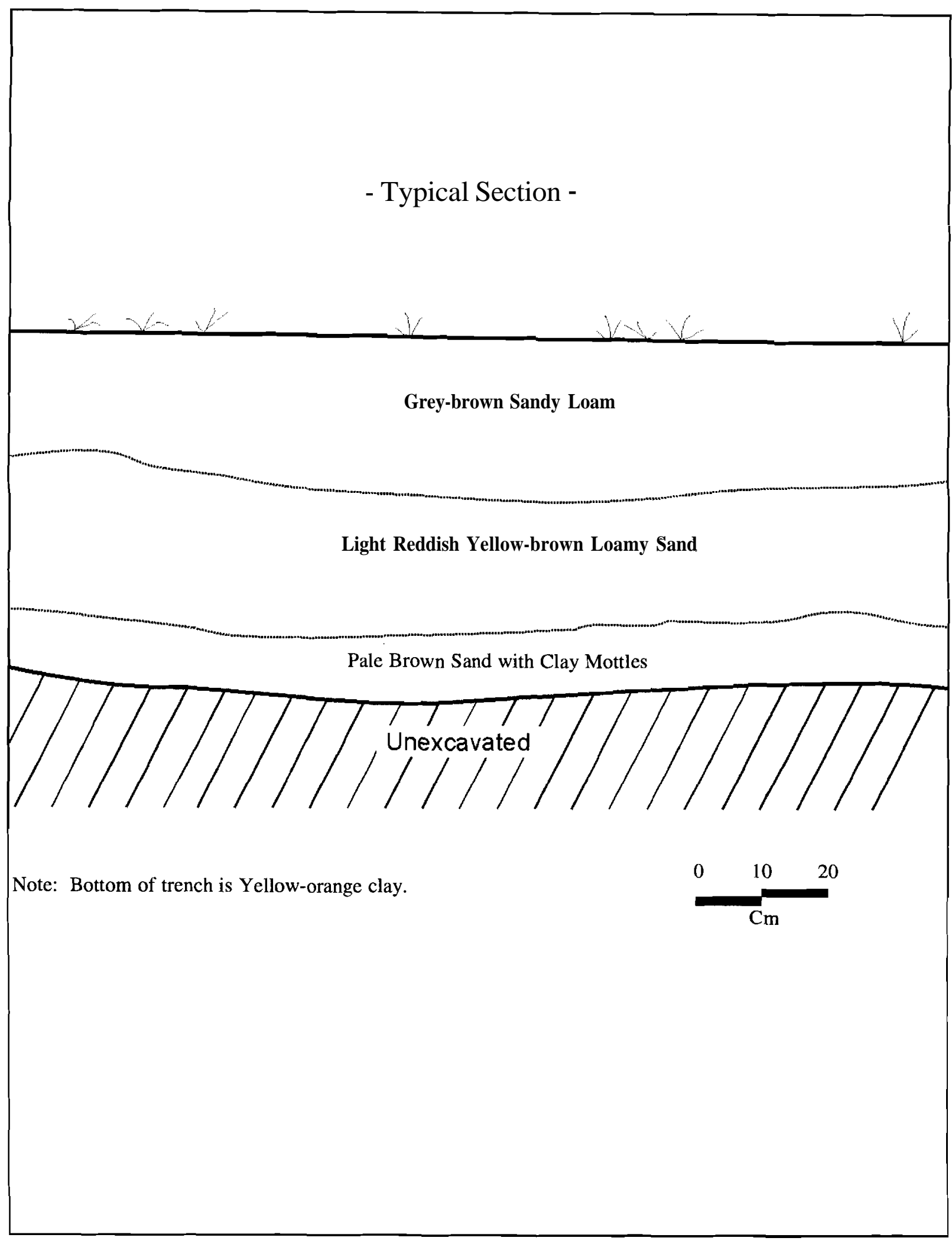

Figure 6. Profile of east wall, gradall trench 6, Area A. 
Table 4. Distribution of ground stone tools from 41SM203

\begin{tabular}{|c|c|c|c|c|c|c|c|c|c|c|c|c|}
\hline \multicolumn{9}{|c|}{} & \multicolumn{9}{c|}{ UNITS } & & & \\
\hline Depth (cm) & TP1 & TP2 & TP4 & TP6 & TP11 & GT1 & GT3 & GT7 & GT9 & BT3 & GT6-A & Total \\
\hline $0-10$ & & & & & & & & & & & & 0 \\
\hline $10-20$ & & & & GF & & & & & & & & 1 \\
\hline $20-30$ & & & & & GF & & & & & & & 1 \\
\hline $30-40$ & & PF & & & M & & & GF & & & M & 4 \\
\hline $40-50$ & & GF,PS & 2PS & & & & & & & & & 4 \\
\hline $50-60$ & & & & & & PM & PM & & & & & 2 \\
\hline $60-70$ & & & & & & PS & & & & & & 1 \\
\hline $70-80$ & 2GF & & & & & & & & & & & 2 \\
\hline $80-90$ & & & & & & & & & & & & 0 \\
\hline $90-100$ & & & & & & & & & & & & 0 \\
\hline $100-110$ & & & & & & & & & M & & & 1 \\
\hline $110-120$ & & & & & & PS & & & & & & 1 \\
\hline Unknown & & & & & & & & & & PS & & 1 \\
\hline & & & & & & & & & & & & \\
\hline T=18 & 2 & 3 & 2 & 1 & 2 & 3 & 1 & 1 & 1 & 1 & 1 & 18 \\
\hline
\end{tabular}

Legend:

$\begin{array}{ll}\text { GF-Ground Stone } & \text { M-Mano } \\ \text { PF-Pitted Slab Fragment } & \text { PM-Pitted Mano } \\ \text { PS-Pitted Stone } & \end{array}$

specimens) account for $43.6 \%$ of the total assemblage. When compared to all other flakes with platforms (DC 1 , $2,5,6)$, the figure is $83.8 \%$. When contrasted with the hard-hammer flakes alone, the difference of $97 \%$ to $3 \%$ is even more striking. From these statistics, it appears that in the sampled portions of this site it was soft hammers that were used almost exclusively.

The explanation for this is in part the same as the explanation for the low percentage of hard-hammer flakes. That is, the kinds of material available often dictate the kind of reduction. In the absence of an abundant supply of local stone, the site's inhabitants had to carry in stone from some distance. For the most part, this material seems to have arrived in the form of modest-size to small bifaces (blanks and preforms) and possible decorticate cores (only one possible core fragment was found).

Soft hammers were then used to reduce the blanks, preforms, and cores into the necessary tool forms. They probably were then further used to refurbish these tools or others, including unifaces or modified flakes, that came to the site ready made.

\section{5-6 (Unknown Method)}

These categories are for flakes of unknown, or indeterminate, manufacture that usually lack telltale features of a particular method or have a combination of features. Reflecting this in-between character, thesde categories often fall numerically between DC 1-2 (hard 
hammer) and DC 3-4 (soft hammer), having more than the hard-hammer group and fewer than the soft-hammer group. From this site, DC 5-6 hold true to this pattern, having a combined total of 31 specimens or $7 \%$ of the total sample. Of flakes with platforms, this would be $13.5 \%$ of the total, which is approaching the figure (15 to $20 \%$ ) that is common in central Texas and elsewhere (according to the particular views of the present analyst).

\section{7 (Flake Fragments):}

This category consists of the flake fragments that lack platforms, and is usually the largest category of a collection, as it is here with $47 \%$ (205 specimens). More often than not, the percenage of flake fragments is even greater than this. Though limited information comes from this category, it nevertheless can be useful. This is mainly for giving an accurate picture of material type, but also for helpful approximations of size, cortex, burning, and patination.

\section{8 (Shatter):}

In most collections of any size there are specimens that lack the features of ordinary flakes. Such pieces can be produced in many ways, but especially in situations when heavy, hard-hammer percussion is used. For example, certain shatter debitage is an indicator of hammer/anvil percussion. The Shatter category is tied with the hard-hammer flakes for being the smallest category at the site and has no significance at all.

\section{Flake Size}

Another important variable of the assemblage is size. This varible bears on several significant and usually interrelated aspects of an assemblage, such as 1) the proximity of raw material, 2) the form of raw material or blanks, and 3) the kinds of tools made at the site. The present assemblage is of remarkably small average size. Fully $89.3 \%$, or 393 specimens, of the flakes and fragments are less than $20 \mathrm{~mm}$ in maximum dimension. Of the larger pieces, in the $21-30 \mathrm{~mm}$ range there are 40 specimens, or $9.1 \%$. Next, in the $\mathbf{3 1}-40 \mathrm{~mm}$ range there are 5 specimens, or $1.1 \%$. The final $2(0.5 \%)$ and largest specimens are between 41 and $50 \mathrm{~mm}$ in length.

In an assemblage such this from 41SM203, an overwhelming percentage of very small flakes is often an indicator of the availability of local raw material, which is to say there was very little of it around site 41SM203. A fuller picture of raw material sources emerges, then, when this statistic is linked to other factors such as material type, flake type, and cortex.

\section{Cortex}

The final primary variable to be discussed is cortex. The amount of cortex on individual specimens and in an assemblage as a whole is a useful indicator that reflects on several aspects of acquiring and reducing lithic materials. Cortex is often the best indicator of how close a site was to raw materials. At the same time, cortex (or the lack of it) is an indicator of the stages of reduction that occurred at a site. Very little cortex usually means that there was little primary reduction, and possibly not much secondary reduction.

While discussing several of the previous variables, it was noted that there does not appear to have been a substantial quantity of knapping stone in close proximity to site 41SM203. The low percentage of cortex is seen as corroborating this aspect of the local raw material.

There are different ways to record the cortex of an assemblage, but in view of the small amount in the present one, it was recorded as primary, secondary, and tertiary (none). However, it is being presented in a simpler form, as merely being present on a specimen (it was also observed that there were only two small primary [100\% cortex] cortex flakes). The total number with cortex is only 64 , which is $14.5 \%$ of the sample. Of this total, a large majority had only a small amount of cortex.

In sum, the explanation for the low percentage of cortex is probably a fairly standard one, but with two parts. Since 1) there was not much in the way of locally available stone, the 2) initial stages of core and biface reduction, which produce most of the cortex flakes, were not done at this site. Of course, raw material with much cortex could have been imported into site 41 SM203, but it apparently was not.

\section{Regional Pattern}

The debitage found at site 41SM203 fits a pattern frequently seen across the northeastern Texas region. The notable features of this pattern are: 1) relatively low debitage to tool ratio, 2) extremely low percentage of hard-hammer flakes, 3) high percentage of soft-hammerflakes, 4) greatest percentage of flake fragments, 5) extremely small average flake size, and 6) low incidence of cortex.

As a rule, this combination of traits is the result of some or all of the following: 1) local raw materials being relatively scarce and of small size and/or inferior quality, 2) a substantial percentage of raw material being imported into the region, 3) most raw material being substantially reduced before imported, and 4) most of the debitage being from intermediate and final stage reduction or rejuvenation of small bifaces and simple flake tools. 


\section{Other Knapping Methods}

\section{Pressure Flaking}

In addition to the percussion flaking discussed above, there are other knapping methods that were probably used at site 41SM203. First among these is pressure flaking, which almost certainly was done even though no debitage can be confidently attributed to that method. As is often the case, very few flakes were found that might have been made by pressure flaking. This is usually the result of using $1 / 4 \mathrm{in}$. screens; most of the pressure flake fragments fall through. Based on the very small sample of bifaces, the kinds of tools that would have been pressure flaked are mainly dart points.

\section{Indirect Percussion}

Another knapping method possibly used at 41 SM203 is indirect percussion. Although no debitage can be positively linked to this method (typically a difficult thing to do), there are two or three pieces that are possible candidates. These appear to be flakes (fairly large ones) from notching bifaces, and could have been made by either pressure or indirect percussion. There is not yet any evidence confirming the use of indirect percussion in reducing the region's resources, but it might have had its place, as did the hammer/anvil technique.

\section{HAMmer/ANVIL}

Yet another technique sometimes identified in east Texas is hammer/anvil (sometimes called bipolar) flaking. This technique for breaking small rounded stones with hard-hammer percussion might have been useful for some of the presumed local resources, but the collection does not contain any pieces that resemble typical debitage. From time to time it has been suggested that certain itted stones common to the region could have been used as anvils. In those collected from this site, however, the pits seem to be too small to have effectively supported siliceous stones for knapping.

\section{Stone Tools, Ceramics, Organic Materials and Ferruginous SANDSTONE}

\section{Bifacial Artifacts}

The sample of bifacial artifacts recovered from the test excavation is quite small, consisting of three complete dart points, one dart point fragment, and four very small fragments that cannot be linked to a particular type of tool. Although the dart point sample is small, when it is added to the three dart points found during shovel testing the result is thought to be a fairly good indication of the major time of occupation at the site.

Of the three specimens, two are the Gary type (Fig. 7, A, B), with the third being most like the Yarbrough type (Fig. 7, C). In many parts of northeastern Texas these are the two major types of the Late Archaic, with the Gary and Kent types (and possibly others) carrying over into the Early Ceramic period.

The dart point fragment is the distal section of a narrow, fairly-thick point that resembles the Gary type; it is made of quartzite. The obvious Garys are made of fine-grained quartzite (fgq) and silicified wood (sw), while the possible Yarbrough is made of tan flint; thus, each point is made of a different material. The four small fragments are all of flint.

Metric dimensions $(\mathrm{mm})$ of the dart points are as follows:

$\begin{array}{lccc} & \text { Length } & \text { Width } & \text { Thickness } \\ \text { Gary (fgq) } & 48 & 25 & 8.5 \\ \text { Gary (sw) } & 48 & 22 & 7.5 \\ \text { Yarbrough } & 47 & 22 & 6.0\end{array}$

Of the three dart points found during shovel testing, two (one Gary and one Gary/Kent) are also from the Late Archaic or Early Ceramic periods. The other dart point is a much older, partially patinated point that may be middle or early Archaic.

\section{Modified Flake ToOls}

Of the 440 flakes and fragments in the assemblage, 10 stand out as having some kind of modification related to use or tool manufacture. Predictably, the five specimens that are complete are among the largest flakes in the assemblage but, even so, only one is as much as 30 $\mathrm{mm}$ in length. All specimens are relatively narrow and some are extremely thin; the thickness range is from 2.0 $\mathrm{mm}$ to $5.0 \mathrm{~mm}$.

Several specimens (Fig. 7, D-G) have abrupt retouch or use damage with edge angles around 80 degrees. Other pieces have retouch that may be platform preparation rather than use damage. Only one specimen has fairly extensive trimming that resembles that of a formal tool. Another has very light trimming and/or use damage that gives the appearance of an end scraper. Only very minor use wear exists on these tools, occurring mostly as light edge rounding and nicking. Some specimens apparently were used for cutting while others could have served in light scraping activities. 
Nine of the ten specimens in this sample are made of flint, clearly reflecting that it was either the best, preferred, or most readily available material for both chipped and expedient tools.

\section{Ceramics}

The test excavation of 41SM203 produced only six small ceramic sherds to go with the one found during shovel testing. This collection consists of small body sherds (Fig. 7, H,I), only one of which has a maximum dimension greater than $25 \mathrm{~mm}$. In terms of thickness, one sherd is $11 \mathrm{~mm}$, four sherds are $8 \mathrm{~mm}$, and two are $6 \mathrm{~mm}$.

Ceramics were confined to one small part of the site which includes TP 4, TP 11, and two previously dug shovel tests. These several sherds were fairly similar in terms of color, temper, and surface decoration. The exterior surface and paste of all seven specimens have mainly a light yellowish brown, or tan, color, while the interior surfaces are mostly a dark yellowish to grayish brown. Grog is by far the major tempering agent, but there is also a minute amount of bone. Of the seven sherds, five have brushing, the only kind of decoration in the sample. The sherds quite likely derive from the latter part of the Caddoan era.

\section{Ground Stone Artifacts}

The final category of artifacts from site 41SM203 consists of various tools made of ground stone (Table 4). Included in this category are 3 manos, 2 pitted manos, 6 pitted stones, 6 ground stone fragments, and 1 pitted slab fragment. These artifacts were widely spread across the site, but the majority occurred along the apex of the ridge in Area B. This was also the area where a majority of other artifacts were found.

Only one specimen, a mano, was found in Area A, but during the previous shovel testing, two small manos were found in the immediate vicinity. The only diagnostic artifacts found in this area were also dart points. One was found during shovel testing and another was found in a Gradall trench during the test excavation; both specimens would seem to be from the Late Archaic period. Although they could possibly be from the Early Ceramic period, there are no ceramics present to suggest the Early Ceramic period.

The largest and only complete mano (Fig. 7, J) has the following metric dimensions: $\mathrm{L}-83, \mathrm{~W}-66, \mathrm{~T}-33$. The dimensions of the largest pitted stone are: $\mathrm{L}-125, \mathrm{~W}-90, \mathrm{~T}$ -55. The dimensions of the largest ground stone fragment are: $\mathrm{L}-145, \mathrm{~W}-77, \mathrm{~T}-40$. At least two of these tools appear to be complete, while the other ground stone tools are fragmentary.

\section{Organic Material and Ferruginous SANDStone Fragments}

Small amounts of fragmentary, burned nutshell were recovered from TP 1 and TP 3 . These units lie along the ridgetop where the greatest numbers of artifacts were found. In TP 1, nutshell fragments occurred in Levels 11 and 12 at a depth of $100-120 \mathrm{~cm}$. In TP 3, a single fragment of nutshell was found in Level $12(110-120 \mathrm{~cm})$, approximately 20 fragments came from Level 17 (160 - 170 $\mathrm{cm})$, and another 3 fragments occurred in Level 18 (170 $180 \mathrm{~cm})$. All of these fragments are quite small, but some retain characteristicsof hickory nuts.

In both TP 1 and TP 3, artifacts occur in the same levels as the nutshell, but, with only one exception, these are very small numbers of flint flakes. The exception is a Late Archaic dart point from TP 1.

Numerousfragments of ferruginous sandstone were also found along the ridgetop at 41SM203. Small pebbles of this material were widespread across the site, but in the vicinity of TP $1, T P 2$, and two shovel tests from the survey, there were larger pieces that might have resulted from cultural activity. The larger fragments were large pebble and small cobble size and, although none were obviously burned, some might have been modified by heat. Other fragments could have the detritus from shaping ironstone into tools. In TP 1 and shovel test 1 , the larger sandstone fragments were mostly at a depth of $50-70 \mathrm{~cm}$. Nowhere did they occur in a pattern that resembled a cultural feature. 


\section{Aboriginal Activities at Site 41SM203}

The picture of the prehistoric occupation of site 41 SM203 is one seen fairly often across northeastern Texas. The use of site $41 \mathrm{SM} 203$ by prehistoric peoples resulted in a modest sample of extant artifacts that are mostly made of stone. From these tools and debitage, a few ceramic sherds, and a few fragments of charred nut shell, it is possible to identify or to infer some of the major activities carried out in this locale. However, for several reasons only very general statements can be made about these activities. The principal reason is that the material assemblage did not come from discrete components.

All classes of artifacts from 41SM203 contribute in various degees to understanding human behavior at the site. The lithic debitage, for example, is only the discarded material from tool preparation, but it is still the most abundant artifact class and as such offers some insight into various aspects of aboriginal behavior that occurred both on and away from the site. For example, it has been learned that the aborigines came into this locale carrying their chipped-stone-tool materials; they did not come here to find raw material.

Of the materials that these hunters and gatherers carried, a majority is believed to have come from sources toward the west. Some of these sources may not have been very distant, perhaps coming from upland gravel deposits within the Neches River drainage. Other materials, however, appear to derive from sources much farther to the west, perhaps as far away as central Texas. It is not suggested that the indigenous population traveled that far for stone, but more likely came by it through trade, possibly at planned annual meetings. Perhaps the most significant finding of the debitage study is that for this locale the major region for acquiring stone was to the west rather than the northeast, or elsewhere.

In addition to addressing the standard issues of tool manufacture, raw material availability, and raw material sources, the debitage is helpful when considering the intensity and horizontal parameters of site usage. At site 41SM203, the lithic debitage clearly indicates that a majority of flint tool working occurred along the ridgetop in Area B. Also found there were a few dart points and about a dozen ground stone tools, in both cases a majority of the overall sample. All together, the findings point to the ridgetop being the focus of certain activities such as flint tool making and possibly the collection and preparation of hardwood nuts. In view of the material sample, then, it can be inferred that the ridgetop was probably the major camping area at the site during the Archaic period, and that many other activities that left no traces also were carried out there.

Another major activity locus, that probably included camping, is believed to have been in Area A near the creek (and, presumably, the springs). However, the artifact sample from this area was much smaller, with very little lithic debitage, but three grinding tools were found, along with two dart points. The sandy deposit there averages only about $40 \mathrm{~cm}$ in depth.

Although seemingly well placed today, site 41SM203 was not always an attractive location in prehistoric times. Beyond a single dart point, evidence was not found that the site was inhabited prior to the Late Archaic period. Although the evidence for this period is relatively meager, it is still by far the dominant component at the site. This fact would seem to bear on issues such as population growth and settlement patterns. That the Late Archaic was the dominant period at 41SM203 is in accord with the regional pattern of Late Archaic dominance and presumed population growth.

Site 41SM203 is seen as having been a potentially habitable, although seldom-used location through most of the Archaic era, but saw an intensification of use in the Late Archaic. Even then, however, it would appear that the occupations were neither very intensive nor frequent. This assessment, is should be stressed, is based on the recovered material culture alone and thus may not be altogether reliable. The 440 flakes, 18 ground stone items, and 7 dart points recovered are, of course, but a fraction of the assemblage that remain in the site. Extrapolating from these figures, the site as a whole very likely contains thousands of flakes and scores of ground and chipped stone tools.

Covering several environmental zones, the site area probably offered a good variety of resources, including hardwood nuts and acorns, and, most importantly, water. A variety of game would have been attracted to the same environmental zones and to some of the same resources.

Following the Late Archaic, no evidence was found that people of the Early Ceramic period used the site, although evidence of that era could easily lie in the uninvestigated portions. At a much later time, the site was used during the Caddoan era but, according to the findings, this was for only a brief period toward the latter end of the Caddoan era. 


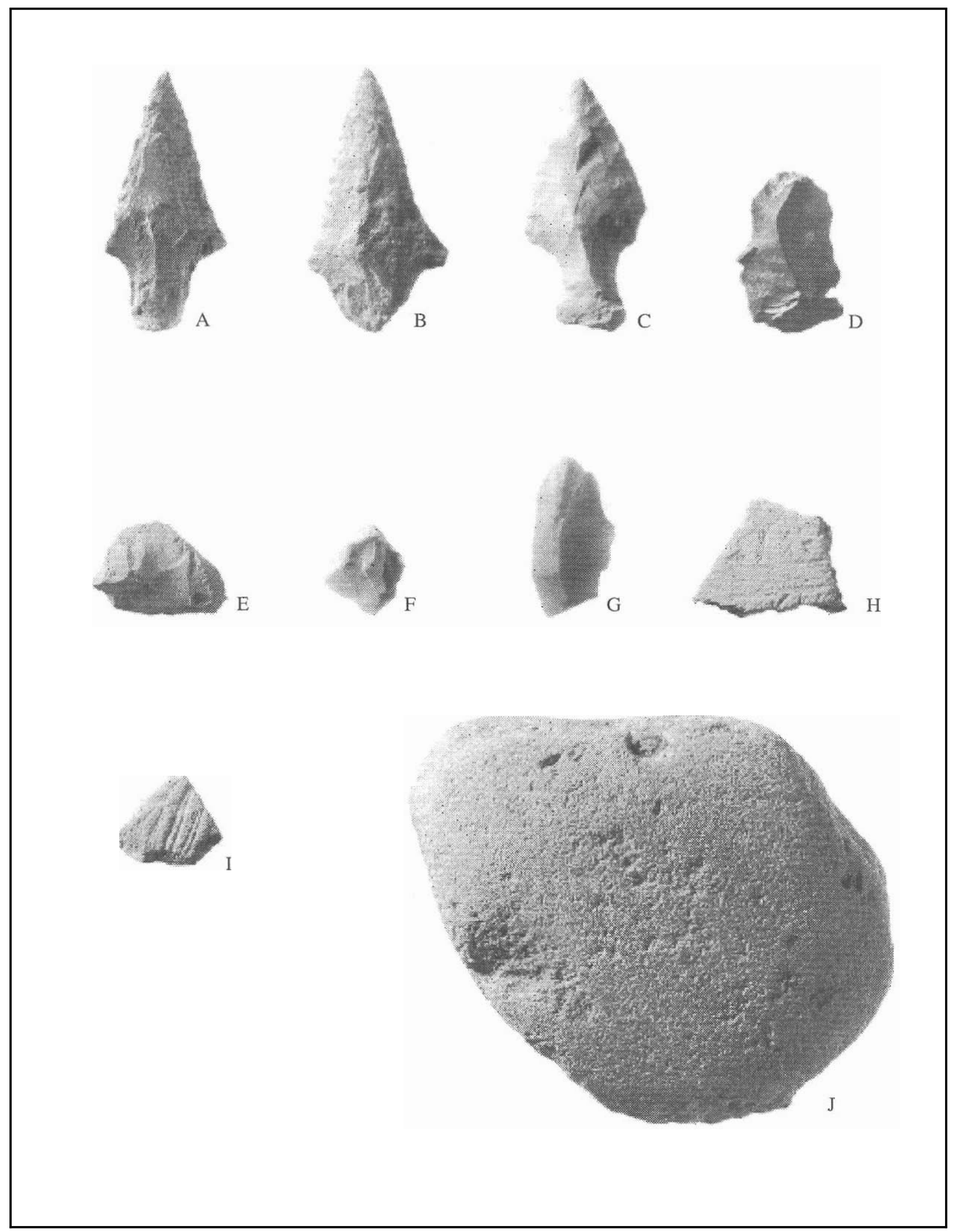

Figure 7. Prehistoric artifacts from 41SM203. 


\section{Summary and Recommendations}

The test excavation of site 41SM203, done within a one-week time frame, exposed enough of the site and its contents to allow a recommendation regarding the question of eligibility for inclusion in the National Register of Historic Places (NRHP), but only for that part of the site to be affected by the proposed roadwork.

During the investigation, the site was confirmed as being quite large and relatively deep in places. More importantly, however, it was not found anywhere to be stratified, to have discrete components or to have significant concentrations of artifacts, nor did it produce any cultural features. What was found was a modest assemblage of mostly lithic artifacts, spread from the top to the bottom of the sandy deposit without any meaningful patterns. These aspects of the site, which bear on its significance, make the site fairly "typical" of a particular class of site that is widespread throughout the northeastern Texas region. Such sites often lack the potential for significantly furthering the study of aboriginal lifeways, and 41 SM203 appears to fit this pattern.

The small collection of diagnostic artifacts from the site is seen as being potentially representative of the area investigated, but possibly not of the site as a whole. From latest to earliest, these materials are from the late
Caddoan era, the Late Archaic, and the Middle or Early Archaic. Whether or not the site was actually inhabited during all of these periods cannot be demonstrated. However, it is thought likely that the site was used very sporadically during the earlier two-thirds of the Archaic, then used more intensively during the latter third.

Following that, there may not have been much, if any, habitation until the late Caddoan period. It remains possible that uninvestigated portions of the site were used at times not recognized within the investigated portion.

From the fairly narrow, linear section through site 41SM203 that was investigated, the site can be characterized as primarily having been an Archaic campsite and resource procurement area, very much like many others of the northeastern region of Texas. The greater portion of the site lies along a high sandy ridge, the kind of setting especially favored by people throughout the Archaic period, and primarily Archaic materials were found. These materials, however, were neither sufficiently abundant nor in the kind of discrete context essential to being considered significant.

For these reasons, that part of site 41SM203 to be impacted by the proposed extension of Grande Boulevard is not considered to be eligible for inclusion in the National Register of Historic Places. 


\section{References Cited}

Anderson, Keith M.

1971 Archaeological Resources of Lake Palestine, Texas. Archaeology Research Program, Department of Anthropology, Southern Methodist University, Dallas.

1972 Prehistoric Settlement of the Upper Neches River. Bulletin of the Texas Archeological Society 43:121-198.

Blair, W. F.

1950 The Biotic Provinces of Texas. Texas Journal of Science 2:93-117.

Bruseth, James E., Joe T. Bagot, Kimball M. Bankes, and Mary A. McKinley

1977 Archaeological Research at Lake Fork Reservoir: Site Inventory and Assessment. Research Report 87. Archaeology Research Program, Department of Anthropology, Southern Methodist University, Dallas.

Bruseth, James E., and T. K. Perttula

1981 Prehistoric Settlement Patterns at Lake Fork Reservoir. Texas Antiquities Permit Series, Report No. 2. Texas Antiquities Committee, Austin, and Southern Methodist University, Dallas.

Collins, Michael B., and C. Britt Bousman 1993 Cultural Implications of Late Quaternary Environmental Change in Northeastern Texas. In Archeology in the Eastern Planning Region, Texas: A Planning Document, edited by Nancy Adele Kenmotsu and Timothy K. Perttula, pp. 4967. Department of Antiquities Protection, Cultural Resources Management Report 3. Texas Historical Commission.

Fenneman, Nevin M.

1938 Physiography of Eastern United States. McGraw-Hill, New York.
Fields, Ross C. (editor)

1990 Excavations at the Charles Cox, Lambs Creek Knoll, and Buffalo Branch Sites, Jewett Mine Project, Leon and Freestone Counties, Texas. Prewitt and Associates, Inc., Austin, Texas. Reports of Investigations 70. Geologic Atlas of Texas

1965 Tyler Sheet. Bureau of Economic Geology, Austin, Texas.

Gibson, J. L.

1982 Archeological Reconnaissance in the Big Sandy Drainage Basin: An Empirical Approach to Investigating Settlement in East Texas. Submitted to the Department of the Army, Corps of Engineers, Fort Worth District, under Contract DACW6380-C-0041, by Archeology, Inc., Lafayette, Louisiana.

Guy, Janice A.

1990 Previous Archeological Investigations. Chapter 3 in The Archeology and Bioarcheology of the Gulf Coastal Plain: Volume 1, by Denn Story, Janice A. Guy, Barbara A. Burnett, Martha D. Freeman, Jerome C. Rose, D. Gentry Steele, Ben W. Olive, and Karl J. Reinhard, pp. 27-130. Research Series 38. Arkansas Archeological Survey, Fayetteville.

Hatherly, Don T.

1993 Soil Survey of Smith County, Texas. U.S. Department of Agriculture, Soil Conservation Service.

Howard, Margaret

1996 Archeological Survey of Tyler State Park, Smith County, Texas. Texas Parks and Wildlife Department. Austin, Texas. 
Johnson, LeRoy, Jr.

1958 Appraisal of the Archeological Resources of Blackburn Crossing Reservoir, Anderson, Cherokee, Henderson, and Smith Counties, Texas. Department of the Interior, National Parks Service.

Submitted to the Inter-Agency Archeological Salvage Program, Austin, Texas.

Krieger, A. D.

1946 Culture Complexd Chronology in Northern Texas. Publication 4640. The University of Texas at Austin.

Perttula, Timothy K., Bob D. Skiles, Michael B. Collins, Margaret C. Trachte, and Fred Valdez, Jr.

1986 "This Everlasting Sand Bed": Cultural Resources Investigations at the Texas Big Sandy Project, Wood and Upshsur Counties, Texas. Prewitt and Associates, Inc., Austin, Texas. Reports of Investigations, Number $\mathbf{5 2}$.

Perttula, Timothy K.

1995 The Archeology of the Pineywoods and Post Oak Savanna of Northeast Texas. Bulletin of the Texas Archeological Society 66:331-359.

Schambach, F. F.

1982 An Outline of Fourche Maline Culture in Southwest Arkansas. In Arkansas Archeology in Review, edited by N. L. Trubowitz and M. D. Jeter, pp. 132-197. Research Series No. 15. Arkansas Archeological Survey, Fayetteville .

Scott, Thomas R., Michael McCarthy, and Mark A. Grady

1978 Archeological Survey in Cherokee, Smith, and Rusk Counties, Texas: a Lesson in Survey Methods. Research Report 116. Archaeology Research Program Department of Anthropology, Southern Methodist University, Dallas.
Shafer, Harry J.

1981 Archaeological Investigations at the Attaway Site, Henderson County, Texas. Bulletin of the Texas Archeological Society 52:147-178.

Skinner, S. A. (assembler)

1981 Cultural Resources Survey of the Troup Mine, Texas. Cultural Resources Program Investigative Report 81-7. AR Consultants, Inc., Dallas.

Story, Dee Ann

1985 Adaptive Strategies of Archaic Cultures of the West Gulf Coastal Plain. In Prehistoric Food Production in North America, edited by Richard I. Ford, pp. 19-56.

Anthropological Papers 75. Museum of Anthropology, University of Michigan, Ann Arbor.

Story, Dee Ann

1990 Cultural History of the Native Americans. Chapter 5 in The Archeology and Bioarcheology of the Gulf Coastal Plain. Volume I, by Dee Ann Story, Janice A. Guy, Barbara A. Burnett, Martha D. Freeman, Jerome C. Rose, D. Gentry Steele, Ben W. Olive, and Karl J. Reinhard, pp. 163-366. Research Series 38, Arkansas Archeological Survey, Fayetteville.

Webb, C. H., F.E. Murphy, W.G. Ellis, and H.R. Green

1969 The Resch Site, 41HS16, Harrison County, Texas. Bulletin of the Texas Archeological Society 42: 1-49. 